\title{
Katarzyna Cieślak*
}

ORCID: 0000-0002-5539-4313

AGH Akademia Górniczo-Hutnicza w Krakowie

\section{PŁEĆ SPOŁECZNO-KULTUROWA \\ JAKO KATEGORIA RÓŻNICUJĄCA PROCES PROJEKTOWY SPECJALISTÓW USER EXPERIENCE}

\begin{abstract}
Niniejszy artykuł jest próbą osadzenia koncepcji płci społeczno-kulturowej w branży nowych technologii, a dokładniej jednym z ich działów - user experience (UX). Problemem badawczym jest odpowiedź na pytanie o to, jak płeć społeczno-kulturowa różnicuje treści procesu projektowego UX. W celu pogłębienia tego tematu oraz poznania doświadczeń i wyobrażeń o kobiecości i męskości w projektach UX zastosowana została metoda badań jakościowych - wywiady pogłębione ze specjalistami user experience. Z przeprowadzonych rozmów zostały wyodrębnione elementy, które rozgraniczają projektowane doświadczenia użytkowników pod względem ich płci (kolorystyka, układ treści, kształtów, zdjęć, grafik).
\end{abstract}

Słowa kluczowe: user experience, gender, feminist HCI, user-centered design

Postępujący proces digitalizacji społeczeństwa przyczynił się do rozwoju koncepcji skupionych wokół pojęcia technologii informacyjno-komunikacyjnych (ICT). Jedną z nich jest interdyscyplinarna dziedzina nauki dotycząca komunikacji człowiek-komputer (ang. human-computer interaction), która zajmuje się projektowaniem technologii komputerowej oraz badaniem interakcji człowieka z interfejsem użytkownika (Carroll b.d.). Pierwszą z subdyscyplin HCI jest metodologia projektowa human-centered design i wyłaniająca się z niej koncepcja budowania pozytywnych doświadczeń użytkownika - user experience.

Human-centered design powstało w latach osiemdziesiątych XX wieku1. Ważnym założeniem tej subdyscypliny było zdefiniowanie człowieka jako fundamentu całego procesu projektowania. Jedna z definicji HCD, która podkreśla znaczenie pracy projektanta, została

* Autor do korespondencji: Katarzyna Cieślak, AGH Akademia Górniczo-Hutnicza im. Stanisława Staszica, Wydział Humanistyczny, ul. Gramatyka 8a, 30-071 Kraków; e-mail: kcieslak@agh.edu.pl

1 Donald Norman, psycholog społeczny, badacz i ekspert w dziedzinie human-computer interaction, autor książki User Centered System Design: New Perspectives on Human-computer Interaction, w której opisał założenia podejścia HCD: „Projektowanie zorientowane na użytkownika to filozofia dizajnu. Zgodnie z nią punktem wyjścia jest dogłębne zrozumienie ludzi oraz potrzeb, które produkt ma zaspokoić. To zrozumienie można osiągnąć przede wszystkim poprzez obserwację, gdyż często ludzie nie są świadomi swoich potrzeb, a nawet przeszkód, które napotykają" (zob. Stawicki b.d.). 
przedstawiona przez Trewisa Lowdermilka. Autor przez pojęcie projektowania zorientowanego na człowieka rozumie metodologię projektowania oprogramowania, która pomaga nie tylko programistom, ale także projektantom tworzyć aplikacje odpowiadające na potrzeby ich użytkowników (Lowdermilk 2013: 6).

Tematem tego artykułu jest próba odpowiedzi na pytanie o to, jak kategoria płci społeczno-kulturowej różnicuje treści procesu projektowego user experience, który jest pojęciem wyłaniającym się z podejścia HCD. W tym celu przedstawię wyniki badań, które przeprowadziłam z projektantami i projektantkami UX. W trakcie rozmów chciałam poznać ich interpretacje oraz wyobrażenia o kobiecości i męskości, rozpatrywane w kategorii płci społeczno-kulturowej. Podstawą metodologii moich badań była technika indywidualnych wywiadów pogłębionych. Przeprowadziłam osiem wywiadów z osobami zajmującymi się budowaniem user experience w projektach aplikacji webowych i mobilnych ${ }^{2}$. Wykorzystanie techniki badań jakościowych pozwoliło na doprecyzowanie nie tylko wyłaniającego się z rozmów obrazu kategorii gender, ale również objaśnienie specjalistycznego języka. Badani, którzy zgodzili się na rozmowę, często posługiwali się słownictwem technicznym, charakterystycznym dla swojej branży. Część empiryczna artykułu została poprzedzona wprowadzeniem teoretycznym do tematu user experience, ale również wyjaśnieniem kategorii płci społeczno-kulturowej rozpatrywanej w perspektywie rozwoju nowych technologii i społeczeństwa informacyjnego. Chęć poznania perspektywy specjalistów tworzących produkty interaktywne skierowane dla kobiet lub mężczyzn stała się jedną z głównych motywacji podjęcia tego tematu. Warto zaznaczyć, że koncepcja płci społeczno-kulturowej w literaturze zajmującej się projektowaniem doświadczeń użytkowników nie jest zbyt często poruszana, zwłaszcza w polskich źródłach. Na stronach anglojęzycznych portali branżowych, takich jak UX Collective (Fonseca 2017), UX Magazine (Marsden 2014) czy Career Foundry (Querini 2020) można znaleźć treści dotyczące UX i gender w formie zbioru praktyk inkluzywnego projektowania (ang. inclusive design patterns). W jednym z artykułów Querini porusza kwestie tego, jak stosować zaimki w treściach i komunikatach na stronach internetowych (microcopy) oraz w jaki sposób pytać o płeć w formularzach internetowych ${ }^{3}$. Z kolei Marsden zaznacza, że ludzie stale redefiniują i negocjują płeć poprzez interakcje, a tym samym przyczyniają się do tworzenia samej płci. Dlatego też budowanie doświadczeń użytkowników jest jej zdaniem formą konstruowania płci - doing gender (Marsden 2014).

Motywacja do projektowania stron internetowych czy aplikacji mobilnych, tak aby były jak najbardziej użyteczne i przejrzyste dla odbiorców, przyczyniła się do rozwoju kilku metod i koncepcji stawiających człowieka w centrum technologicznego świata. Jedną z nich jest user experience, które w polskim tłumaczeniu oznacza „doświadczenie użytkownika” budowane przez specjalistów w kilkuetapowym procesie. Proces ten najczęściej zaczyna się fazą badań i ich analizą, później przygotowaniem modeli użytkowników (tzw. person) i kończy na

2 Pomimo małej próby badawczej to materiał dość szybko nasycił się i wiele wątków było typowych. Poza tym analizy miały charakter eksploracyjny i wprowadzający do zagadnienia.

3 UX writing to technika projektowania treści na stronie w taki sposób, aby były jak najbardziej użyteczne dla jej odbiorców. UX writing powiązany jest z pisaniem mikrotekstów (microcopy) dla interfejsów aplikacji, które pomagają w nawigacji po danym interfejsie graficznym, np. aplikacji mobilnej, formularzu, blogu. Wymienione w tekście przykłady pochodzą z artykułu na temat inkluzywnych praktyk projektowych (Querini 2020). 
tworzeniu prototypów, które są wdrażane do finalnych wersji produktów cyfrowych (Tidwell 2012: 18). Każdy z tych etapów został poddany analizie pod względem pojawiających się w nich wyobrażeń specjalistów UX na temat odbiorców tworzonych produktów cyfrowych.

Wraz z rozwojem technologii, które skupiają się na tworzeniu doświadczeń jednostek wchodzących $\mathrm{w}$ interakcje z efektami cyfrowej rewolucji kategorie, które były już poruszane przez klasyków socjologii, nabierają nowego znaczenia. Jedną z nich jest płeć społeczno-kulturowa, która w niniejszym artykule jest analizowana w obszarze budowania pozytywnych doświadczeń użytkownika.

Odpowiedzią na zauważalne zmiany w kontekście społecznym stała się teoria Manuela Castellsa dotycząca społeczeństwa sieci. Jej wielopłaszczyznowy charakter dobrze obrazuje, w jak wielu aspektach technologie rozwinęły się i wchodzą w reakcje ze społecznościami. Castells definiuje społeczeństwo sieci jako strukturę społeczną opartą na sieciach, „Jednak nie na każdym rodzaju sieci, ponieważ sieci społeczne były istotnym wymiarem życia społecznego od początków ludzkości. Sieci charakterystyczne dla współczesnej organizacji społecznej to sieci informacyjne wspierane przez nowe technologie komunikacyjne" (Castells 2008: 345). Powyższe zależności mogą mieć znaczenie w sposobie tworzenia i interpretowania stron internetowych przez obydwie płcie.

Osoby biorące udział w moich badaniach pracowały w polskich firmach. W tym miejscu warto wspomnieć, że branża user experience w Polsce jest obszarem stosunkowo nowym. Pierwszy ogólnopolski raport analizujący jej przedstawicieli powstał w 2011 (Mościchowska et al. 2011). Od tego czasu pojawiło się wiele organizacji specjalizujących się w przygotowaniu użytecznych, atrakcyjnych i dostarczających pozytywnych doświadczeń dla użytkowników produktów interaktywnych. Każda z tych firm przyczyniła się do rozwoju samego zawodu projektanta user experience, który to $\mathrm{w}$ tak krótkim czasie zyskał kilka nowych określeń oraz przyczynił się do utworzenia innych specjalizacji w tym obszarze. Osoby zajmujące się projektowaniem doświadczeń należą do grupy specjalistów, którzy w swojej pracy często wytwarzają oraz definiują wzorce kobiecości i męskości przez tworzenie stron lub aplikacji dla określonych pod względem płci odbiorców.

\section{PŁEĆ SPOŁECZNO-KULTUROWA W SPOŁECZEŃSTWIE INFORMACYJNYM}

W klasycznej socjologii płeć była rozpatrywana głównie w kategoriach biologicznych. Skupiano się na definiowaniu ról płciowych lub procesów socjalizacyjnych norm płciowych. Definiowanie kobiecości i męskości w teoriach klasyków, takich jak Herbert Spencer, Emile Durkheim czy Talcott Parsons było rozpatrywane z perspektywy naturalnie uwarunkowanych różnic emocjonalnych, intelektualnych czy poznawczych, które ujawniają się w rolach społecznych, odmiennych potrzebach czy systemach wartości (Marshall 2002: 136-142). Warto zaznaczyć, że podstawą założeń widocznych w interpretacjach klasyków były przekonania ugruntowane w XIX-wiecznej psychologii czy medycynie podkreślającej dymorfizm płciowy (Leszczyńska i Dziuban 2012: 14). Zauważalne różnice pomiędzy kobiecością a męskością zdaniem autorów klasycznych koncepcji socjologicznych sprowadzały się do rozgraniczenia 
na kilka obszarów, takich jak cielesność i umysłowość, irracjonalność, uczuciowość i rozumność oraz rozumienie wartości kolektywnie lub indywidualistycznie (Bradley 2008: 14). Zdaniem Raewyn Connell definiowanie płci poprzez dychotomie „wyklucza z pojęcia płci różnice występujące w obrębie każdej z grup - między kobietami i między mężczyznami”. Zdaniem australijskiej badaczki, definiując płeć, warto skupić się na relacjach społecznych, wokół których istnieją zarówno jednostki, jak i grupy (Connell 2013: 29-30).

$\mathrm{W}$ trakcie rozmów z projektantami podjęłam próbę pogłębienia tematu przypisywania różnych cech do odbiorców tworzonych przez nich treści. Jednym z powodów była chęć sprawdzenia, czy skojarzenia przedstawicieli współczesnej profesji pokrywają się z teoriami przedstawicieli klasycznej socjologii.

Kategoria płci społeczno-kulturowej stała się przedmiotem rozważań również współczesnych przedstawicieli nauk społecznych. Powstało wiele różnorodnych definicji traktujących płeć jako fenomen społeczny. Przełom w postrzeganiu płci społeczno-kulturowej w odmiennej niż biologicznej perspektywie nastąpił w latach osiemdziesiątych (Leszczyńska i Dziuban 2012: 14-15). W tym czasie powstała praca Ann Oakley - Sex, Gender and Society. Zdaniem badaczki, płeć jest związana ze społeczno-kulturowym rozumieniem bycia kobietą lub mężczyzną, czyli dotyczysposobu określania norm męskości i kobiecości przez społeczeństwo (Bradley 2008: 27). Podczas przeprowadzania wywiadów z projektantami UX zauważyłam, że w swoich projektach podkreślali własne definiowanie płci w formie kształtów przycisków czy ułożenia grafik. W opozycji do teorii Oakley, gdzie zwraca się uwagę na dychotomie pojęcia płci społeczno-kulturowej, pojawiła się koncepcja Judith Butler. Zdaniem badaczki nie istnieje podział na płeć biologiczną i płeć kulturową, stwarzane są one w tym samym czasie (Butler 1990, za: Bradley 2008: 140).

Jedna $\mathrm{z}$ tez postawionych przez Harriet Bradley dotyczy ukazania płci skonstruowanej społecznie, rozumianej przez jednostki jako ,element strukturyzacji postrzeganego przez nich świata, nadając mu określone znaczenia" (Bradley 2008: 14). W tym ujęciu płeć zyskuje pewnego rodzaju dynamikę, która zależy od czasu, miejsca i kultury, w której jest wytwarzana. Szczególne znaczenie dla tematu niniejszego tekstu ma właśnie definiowanie kategorii gender jako społecznego konstruktu, który kształtowany jest również w obszarze produktów cyfrowych. Temat płci jako praktyki społecznej stał się popularną koncepcją w naukach społecznych, często podkreślając jej dynamiczny charakter. Warto w tym miejscu zwrócić uwagę na zagadnienie konstruowania płci w codziennych praktykach (tzw. doing gender) autorstwa Candace West i Don Zimmerman powstałe w 1987 roku (Connell 2013: 129). Główne założenie powyższej koncepcji to teza, że zachowania kobiet i mężczyzn nie są wynikiem płci, ale formą określenia jej istoty. Płeć wobec tego nie jest zastana, a wytwarzana przez aktorów społecznych, choć nie w sposób woluntarystyczny. Jak pisze Connell, tworząc płeć, jesteśmy ograniczeni porządkiem płci. Poruszając kwestie konstruowania płci w społeczeństwie, warto zwrócić uwagę na definiowanie „znaczeń płci” (Connell 2013: 130). Temat ten został przeze mnie pogłębiony w trakcie przeprowadzania wywiadów. Poprosiłam moich rozmówców o przybliżenie ich wyobrażeń na temat końcowych odbiorców projektowanych rozwiązań, aby lepiej poznać ich perspektywę definiowania płci.

Proces projektowy user experience wynika z potrzeby rozwijania doświadczeń interakcji jednostek wyłaniających się ze społeczeństwa, które szczególne znaczenie przypisuje 
informacji. Powstało kilka określeń, które ewoluowały wraz z rozwojem technologii informacyjnych. Mam na myśli tutaj społeczeństwo wiedzy, sieci czy postindustrialne. Zdaniem Tomasza Gobana-Klasa, występuje kilka elementów charakteryzujących społeczeństwo informacyjne. Po pierwsze, to dominacja pracowników w sektorze informacji oraz duży rozmiar przepływu informacji. Po drugie, relacje między jednostkami mają charakter interakcyjny. Zauważalna jest integracja i konwergencja działań mediów oraz tendencje globalne (Goban-Klas 1999: 304). Powyższe cechy mogą nieść ze sobą swego rodzaju praktyki społeczne, gdzie płeć społeczno-kulturowa staje się jednym z kluczowych elementów. Istnieje również możliwość włączenia tych praktyk do procesu projektowego interfejsów webowych czy mobilnych. Zwłaszcza w kontekście tworzenia jednolitych zasad projektowania, które wraz z globalnymi tendencjami przenikają również do polskiej branży $\mathrm{UX}^{4}$.

\section{GENDER I TECHNOLOGIA - GŁÓWNE KIERUNKI BADAWCZE}

Tematyka relacji gender i technologii jest złożona i coraz częściej podejmowana. Najważniejsze wątki, które dotyczą prowadzonych przeze mnie analiz, związane są z tworzeniem i odbieraniem efektów technologii (w formie interfejsów graficznych), które mają upłciowiony charakter.

Rozwój sztucznej inteligencji i powiązanych z nią subdyscyplin uczenia maszynowego (ang. Machine Learning), Data Science czy przetwarzanie języka naturalnego (ang. Natural Language Processing) sprawił, że artefakty technologiczne zyskują coraz bardziej „ludzki” charakter ${ }^{5}$. Co za tym idzie, płeć staje się jednym z kluczowych sposobów konstruowania obrazu maszyny humanoidalnej przez takie cechy, jak: głos (Lee et al. 2000; Rodger 2004), ubiór (Bath i Weber 2007), fryzura (Carpenter et al. 2009) czy mimika (Cao et al. 2019). Powyższe elementy i praktyki ich wdrażania do urządzeń opartych na interfejsie graficznym czy głosowym stały się przedmiotem badań między innymi feministycznych studiów nad techniką (ang. feminist technology studies, feminist technoscience, feminist human computer-interaction, feminist human robot-interaction i gender studies in technology ${ }^{6}$ ).

4 Przedmiotem badań był proces projektowy user experience, który od początku rozwoju samej specjalizacji UX często ewoluował. Obecnie ukształtowały się dwa podejścia: wodospadowe i zwinne. Nastawione są one na iteracyjność, częste modyfikacje i adaptowanie się do tych zmian. Często w modelu zwinnym projektant pracuje w tym samym czasie co badacz UX. Zanim jednak dojdzie do wdrożeń programistycznych, trwa etap ewaluacji i konsultacji z klientem. Specjaliści, którzy zostali objęci moimi badaniami, najczęściej pracowali w modelu zwinnym.

5 Machine learning - interdyscyplinarna nauka łącząca informatykę, robotykę i statystykę. Jest rozszerzeniem idei rozwoju sztucznej inteligencji. Celem jest badanie i doskonalenie algorytmów i modeli statystycznych, których używają komputery aby wykonać określone zadanie. Data science - nauka o danych, która wykorzystuje naukowe metody, procesy, algorytmy i systemy do wydobywania wiedzy i jej analizy (zob. Przegalińska i Oksanowicz 2020). Natural language processing łączy dziedziny sztucznej inteligencji i językoznawstwa, zajmując się analizą i tworzeniem tekstów w języku naturalnym.

6 Gender studies w obszarze technologii skupia się na analizowaniu dwóch zagadnień. Pierwsze z nich to problem niskiej liczby kobiet w naukach o technologii i sektorze technologii informacyjnych. Natomiast drugie podejście opisuje sposoby korzystania z technologii zróżnicowane płciowe (zob. Bath 2014). 
Feministyczne studia nad technologią (FTS), które wywodzą się z koncepcji społecznego konstruktywizmu, zakładają, że technologia zawiera w sobie pewne relacje społeczne, obejmujące również relacje płci . Zdaniem badaczek, Joan Pujol i Mariseli Montenegro, dla FTS istotne jest uporządkowanie kontekstów tworzenia i użytkowania, w których to płeć jest integralną częścią kształtowania technologii (Pujol i Montenegro 2015: 179). Dodatkowo proces współtworzenia technologii i gender powinien uwzględniać społeczny wymiar jej wykorzystania (Lohan 2000). Dla projektantów UX może to oznaczać budowanie inkluzywnych rozwiązań, opartych bardziej na kontekście użycia danej technologii niż płci odbiorcy. Takie podejście może zachęcać także do odejścia od praktyk podkreślania stereotypowych założeń widocznych w formie kolorów, kształtów czy grafik wizualnych interfejsów.

Drugą dyscypliną definiującą relacje gender i technologii jest feminist HCI. Shaowen Bardzell w tekście o feministycznym postrzeganiu human-computer interaction porusza kwestie projektowania nowych technologii jako obszaru praktyk konstruowania wzorców kulturowych i stereotypów (Bardzell 2010: 1304). Autorka stawia tezę, że elementy charakterystyczne dla HCI, czyli badania z użytkownikami, prototypowanie lub ewaluacja, tworzą perspektywę postrzegania odbiorców jako podmiotów interakcji, z którymi specjaliści komunikują się poprzez sam styl projektowania (Bardzell 2010: 1306). W nawiązaniu do moich badań mogę stwierdzić, że styl czy sposób budowania UX jest zróżnicowany ze względu na płeć odbiorców i tym samym uwydatnia wyobrażenia badanych o kobiecości i męskości. Innymi słowy, do pozornie neutralnie płciowego obszaru UX wzorce płciowe mogą docierać w formie przekonań projektantów i projektantek o docelowych odbiorcach.

Warto również zaznaczyć, że płeć w obszarze nowych technologii może być przedstawiana i konstruowana z dwóch perspektyw - twórcy i odbiorcy, o czym wspomina Wendy Faulkner, wprowadzając rozróżnienie na gender in technology oraz gender of technology. Pierwsza kategoria definiowana jest jako nadawanie płci w sposób odgórny, czyli określany przez twórców na etapie projektowym. Rezultaty takich praktyk stały się przedmiotem badań, między innymi Corinny Bath i Jutty Weber (2007), Justin Cassell (2002), Friederike Eyssel i Frank Hegel (2012). Wymienieni badacze i badaczki wyodrębnili kilka metod wytwarzania wzorców płciowych w urządzeniach, takich jak roboty humanoidalne, inteligentne głośniki czy gry komputerowe skierowane do określonej płci odbiorców. Należą do nich ludzkie cechy wyglądu i ton głosu skategoryzowane jako męskie lub kobiece, a także tematyka gry odpowiadająca stereotypowym charakterystykom odbiorców. Takie elementy często umacniają pewne przekonania, tworząc swego rodzaju zależności, na przykład cross-gender effect szerzej opisany w artykule

\footnotetext{
Rozwój koncepcji technofemizmu nastąpił w latach osiemdziesiątych XX wieku. Od tego czasu pojawiło się kilka prac takich autorek i autorów, jak: Cynthia Cockburn (1994), Wendy Faulkner (1998), Keith Grint i Rosalind Gill (1995 za: Faulkner 2001), Donna Haraway (1998); Judy Wajcman (1991 za: Adam 2006). Cecilia Asberg i Nina Lykke definiują to pojęcie jako interdyscyplinarny obszar badań, który wyrasta z „feministycznej krytyki sposobów, w jakich płeć przecina się z innymi społeczno-kulturowymi wskaźnikami władzy i tożsamości uwikłanymi w nauki przyrodnicze, medyczne i techniczne, a także w sieci i praktyki socjotechniczne zglobalizowanego świata" (Asberg i Lykke 2010: 299).
} 
Tatsuya Nomura (2017: 4) ${ }^{8}$. Wiedza o powyższych rezultatach może być wykorzystywana i upowszechniona również biznesowo, co oznacza pogłębianie takich praktyk na szerszą skalę. Z kolei tematem różnorodności kulturowej w projektowaniu interfejsów graficznych zajmowali się między innymi Aron Marcus (1993), Teasley Barbee (1994) i Jeanette Hoffman (1999). W jednych z badań wykazano, że owalne kształty ikon w programie do edycji tekstów zaprojektowane dla użytkowniczek nie zostały na etapie badań uznane za bardziej użyteczne. Oznacza to, że pewne założenia twórców powinny być konsultowane z odbiorcami na możliwie jak najwcześniejszych etapach powstawania projektu.

Natomiast druga z wymienionych przez Faulkner perspektyw oznacza poddawanie genderyzacji artefaktów technologicznych w trakcie ich użytkowania. Autorzy i autorki analizujący tę stronę odbioru technologii to między innymi Siegel et al. (2009), Rodger (2004), Carpenter (2009). W swoich badaniach skupiali się na odbiorze neutralnych płciowo ze względu na wygląd urządzeń, które i tak były przyporządkowywane przez odbiorców do danej płci z powodu tonacji głosu czy wypowiadanych treści.

Przedmiotem badań z zakresu tematyki gender i technologii stała się także zależność między wiarą w swoje możliwości a debugowaniem, czyli wyszukiwaniem i naprawianiem błędów w programowaniu. Kobiety biorące udział w badaniu Laury Beckwith et al. (2005), których poczucie własnej wartości było niższe niż mężczyzn, mniej chętnie podejmowały próby rozwiązania nieprawidłowości. Według autorów istnieje związek między doświadczeniem zawodowym badanych kobiet a skłonnością do debugowania. Badane respondentki wykazywały mniejszą skłonności do korzystania z nieznanych im funkcji oprogramowania. Zdaniem autorów eksperymentu, właśnie takie funkcje mogą być kluczowe w naprawie błędów, dlatego powinny być zaprojektowane w sposób zachęcający kobiety do korzystania z nich. Badacze podkreślają, że „dobra strategia projektowa powinna zachęcić kobiety do testowania nowych funkcji, zwiększając dzięki temu ich poziom doświadczenia" (Beckwith et al. 2005: 877). W przeprowadzanych przeze mnie badaniach podjęłam próbę sprawdzenia, jak projektanci UX konstruują ich własne strategie projektowe skierowane do użytkowników określonej płci.

\section{METODOLOGIA BADAŃ}

Zrealizowanie celu badawczego i odkrycie wyobrażeń o kobiecości i męskości w projektach UX było możliwe dzięki wykorzystaniu metodologii jakościowej. W badaniu wzięli udział projektanci, projektantki oraz osoby pracujące w branży user experience jako badacze i badaczki. Dobór próby był celowy, a dotarcie do badanych było możliwe dzięki opublikowaniu ogłoszeń na forach internetowych skierowanych do specjalistów UX. Podstawowy wyznacznik uczestnictwa w badaniu stanowiła praca nad rozwijaniem produktu dla określonej

8 Tatsua Nomura przedstawia wyniki wybranych eksperymentów dotyczących gender i human-robot interaction. W przytoczonych analizach wykazano, że uczestnicy wchodzący w interakcję z robotem przeciwnej płci czuli się bardziej komfortowo niż ci, którzy korzystali z robota tej samej płci (zob. Nomura 2017: 4-5). 
płci odbiorców. Próba badawcza składała się z siedmiu projektantek i jednego projektanta. Większość z moich rozmówców pracuje w firmach zatrudniających do trzydziestu osób?

\section{REALIZACJA BADAŃ - CHARAKTERYSTYKA BADANYCH SPECJALISTÓW USER EXPERIENCE}

Osoby badane, konstruując wyobrażenia o płci, kobiecości i męskości wskazywały na kilka wątków dotyczących kolorystyki, kształtów czy skojarzeń dotyczących płci pojawiających się na etapie badawczym w ich projektach. Natura tych wyobrażeń jest dość stereotypowa, powtarzalna i mało zróżnicowana. To także rozmowy o tym, jak definiowana jest kobiecość i męskość nie tylko przez badanych, ale również przez klientów i zleceniodawców. Podczas rozmów respondenci przypisywali kolorystykę oraz elementy projektowanych stron zróżnicowane ze względu na płeć odbiorcy. Ten etap wywiadów zawierał również wypowiedzi, które prezentowały świadomość badanych o przenikających do projektów własnych przekonaniach. Rozmowy dotyczące stereotypowego myślenia były wartościowe pod względem wyłonienia elementów różnicujących treści procesu projektowego.

Moi badani często podkreślali, że najbardziej czasochłonną i angażującą fazą projektowania jest sam proces badawczy. W trakcie tego etapu stawiane są hipotezy i określany zostaje cel biznesowy. Jedna z badanych nawiązuje również do kwestii doboru próby:

Często się zdarza, że jak tworzymy produkt, którego nie ma jeszcze na rynku, on jest bardzo innowacyjny, to wielkim wyzwaniem, jest to, żeby określić tą grupę docelową, bo tam pojawia się etap badania hipotez, który jest bardzo długi, one są różne i przenikają się, niełatwo jest znaleźć ludzi do wywiadów itd., potem jak już to ,złapiemy”, jak wiemy dla kogo robimy produkt i umiemy określić, tą propozycję wartości, to reszta procesu jest już łatwiejsza. (Projektantka 2)

W przeprowadzonych rozmowach pojawiały się odpowiedzi dotyczące wyzwań, które wychodzą poza powtarzające się $\mathrm{w}$ wypowiedziach sześć elementów procesu ${ }^{10}$. Jedna

9 Podczas analizy przeprowadzonych wywiadów posługiwałam się opracowanym kluczem kategoryzacyjnym. Powstało piętnaście kategorii, które brałam pod uwagę przy analizowaniu zebranego materiału. Pierwsze trzy miały charakter wprowadzający do samego procesu projektowego. Kolejne były pogłębieniem wypowiedzi dotyczących etapów projektowania. Podczas rozmów na temat samego procesu projektowego faza tworzenia person użytkowników stała się wprowadzeniem do tematu płci użytkowników. Był to etap wywiadów, gdzie po raz pierwszy pojawiały się wypowiedzi na temat stereotypów pojawiających się nie tylko w samym procesie, ale również w zespole. Kategorie związane z wyobrażeniami projektantów o odbiorcach zostały wyprowadzone na podstawie doświadczenia z projektów zróżnicowanych płciowo pod względem tematyki.

10 Z uzyskanych w badaniach odpowiedzi wyszczególniłam powtarzające się elementy procesu projektowego:

- zdefiniowanie problemu badawczego,

- określenie problemu biznesowego i celów danego projektu,

- etap badawczy - określenie persony odbiorcy,

- prototypowanie,

- powstanie makiet,

- implementacja. 
z projektantek podkreślała, że najtrudniejsza jest nieprzewidywalność końcowego doświadczenia użytkownika z produktem. Zwróciła również uwagę na duże przerzucanie odpowiedzialności za to doświadczenie właśnie na pracę projektantów, którzy mimo korzystania z technik obserwacji lub przeprowadzania badań w określonych warunkach nie są w stanie jasno określić, jak będzie się czuć użytkownik po pierwszym doświadczeniu z produktem:

Myślę, że największym wyzwaniem jest nieprzewidywalność i to, że do końca nie wiemy, jak to doświadczenie będzie ostatecznie wyglądać. [...] Szczególnie w połączeniu z tym, w jaki sposób mówi się o user experience jest odpowiedzialność na projektancie lub projektantce, że będzie się dało to ,jakoś” zaprojektować, że ta praca zapewni to ostateczne doświadczenie, a wydaje mi się że tak nie jest. Więc sprzeczność oczekiwań z rzeczywistością jest kolejnym wyzwaniem. (Projektantka 6)

Możliwą odpowiedzią na powyższe wyzwania staje się zdaniem jednej z badanych kolejny dość ogólny problem, z którym spotykają się specjaliści user experience. Według mojej rozmówczyni jest to umiejętność empatyzowania z końcowymi odbiorcami projektowanych produktów.

Dla osób, z którymi współpracuję, najtrudniejsza jest faza empatii, czyli wczucia się w potrzeby drugiego człowieka. (Projektantka 5)

Autorka powyższej wypowiedzi zaadresowała wskazane wyzwanie jako jeden z kluczowych elementów procesu projektowego:

Podstawy teoretyczne (teoria inteligencji emocjonalnej) plus narzędzia takie jak mapa empatii w procesie projektowym. Ona zmusza nas do pomyślenia o tym, co użytkownik ma w głowie, co czuje. (Projektantka 5)

Odnosząc się do wypowiedzi Projektantki 6, która podkreślała, że najtrudniejsze jest opanowanie nieprzewidywalności końcowych efektów doświadczenia, znajduję możliwe rozwiązanie w odpowiedzi wcześniejszej badanej. Rozmowy na temat rozwijania wśród projektantów umiejętności empatii stały się podstawą do poznania ich doświadczeń związanych z projektowaniem doświadczeń ukierunkowanych na płeć końcowych odbiorców. Był to moment, w którym zaczęły się pojawiać refleksje dotyczące wyobrażeń o adresatach ich produktów.

\section{WYOBRAŻENIA BADANYCH O KOBIECOŚCI I MĘSKOŚCI}

Moi badani w wypowiedziach wskazywali na etap tworzenia person odbiorców jako fazy procesu projektowego najbardziej generującego stereotypowe założenia. W trakcie przeprowadzonych rozmów respondenci zazwyczaj podkreślali, że jest to moment, w którym

Zestawiając powyższe fazy procesu projektowego z teorią autorstwa Jenifer Tidwell, zauważam, że moi rozmówcy nie wymienili fazy testowania kilku wersji produktu. Dodatkowo nie zostały wprowadzone przez badanych projektantów scenariusze działań odbiorców projektowanych rozwiązań (Tidwell 2012: 18). Poza tymi aspektami nie zauważyłam odmiennych założeń dotyczących procesów projektowania UX. 
definiowana jest również płeć odbiorcy i przypisywane im cechy. Co za tym idzie, pojawiają się pierwsze wyobrażenia projektantów o kobiecości i męskości. W poniższych wypowiedziach znajdują się także doświadczenia badanych związane z próbą zweryfikowania i kontrolowania pojawiających się przekonań.

Zazwyczaj nawet jak nie chcemy, to zaraz sobie coś wyobrażamy i jak podchodzimy do badań, to też automatycznie pojawia się nam obraz jakiejś osoby, grupy odbiorców przed oczami, też często posługujemy się niestety stereotypami i ja mam tak samo - podchodzę do badań, np. mam kobiety w IT, mniej więcej wiem, jaka to jest grupa odbiorców w głowie. To jest błędne podejście i nie powinno być tych wyobrażeń i musimy z tym walczyć, dlatego staramy się mieć taką czystą kartę, jak podchodzimy do badań i potem ją sobie dopiero zapełniamy tym, czego się dowiemy i na podstawie wyników tych naszych badań i zrozumienia tej grupy odbiorców, czy tej osoby tworzyć personę, która faktycznie jest zbudowana na tym, co jest, a nie jest zbudowana na naszych wyobrażeniach, stereotypach, tym, co kiedyś, gdzieś usłyszeliśmy, ale nie wiemy gdzie. (Projektantka 7)

Projektanci w trakcie rozmów, podobnie jak autorka powyższej wypowiedzi, podkreślali, że mają świadomość pojawiających się przekonań w trakcie tworzenia person, czy budują własne wyobrażenia o odbiorcach. Moi rozmówcy zaznaczali, że nie są to celowe zabiegi, zapytani o źródło pojawiających się stereotypów odpowiadali:

Wydaje mi się, że jest to coś zagnieżdżone w naszej wiedzy już od dzieciństwa. [...] My te założenia mamy od najmłodszych lat. (Projektantka 5)

Stereotypy wynikają raczej z takiej niezbadanej potrzeby. To raczej nie są stereotypy moje, tylko stereotypy ogólne, ale jeśli tak, to staramy się być bezstronni, nie patrzymy stereotypowo, ani nie opieramy tego na własnych przekonaniach. Raczej staramy się pomijać te aspekty, a skupić się bezpośrednio na tym, kto może być bezpośrednio użytkownikiem aplikacji. (Projektant 4)

[...] nie wiem trochę, jak odpowiedzieć na te pytania, bo nie chcę wyjść na taką ignorantkę i nie chcę też tak uogólniać, i stereotypizować wszystkiego. (Projektantka 8)

Powyższe odpowiedzi stały się wprowadzeniem do poznania wyobrażeń projektantów o odbiorcach projektowanych doświadczeń. W tym celu poprosiłam badanych o przybliżenie projektów skierowanych do określonej płci. Poniżej zestawiam kilka wypowiedzi dotyczących obrazu „typowej” użytkowniczki. Pierwszy z nich dotyczy projektu strony produktu przeznaczonego dla kobiet:

Wyobrażam ją sobie jako kobietę, która aktualnie jest na urlopie macierzyńskim, więc zajmuje się w domu dziećmi i ma czas, żeby ćwiczyć. (Projektantka 1)

Autorka powyższej odpowiedzi podkreślała, że na potrzeby tego projektu przygotowano trzy różne persony użytkownika. Jedna z opisywanych przez badaną person przedstawia jej wyobrażenia dotyczące obrazu macierzyństwa. Hanna Dębska w artykule dotyczącym interpretacji ciała w teorii Pierre'a Bourdieu zwraca uwagę na kwestie społecznego konstruowania tego tematu. Wypowiedź mojej rozmówczyni można odnieść do fragmentu artykułu Dębskiej przedstawiającego macierzyństwo jako, ,podstawową społeczną rolą definiującą kobietę jako 
Płeć społeczno-kulturowa jako kategoria różnicująca proces projektowy...

rodzicielkę" (Dębska 2015: 25). Trzecia projektantka również uczestniczyła w tym samym procesie projektowym, zapytana o wyobrażenia o użytkowniczkach podkreślała użycie danych z wcześniej przeprowadzonych badań:

Ciężko mi sobie wyobrazić taką typową kobietę, dlatego, że my bardzo jasno sprecyzowaliśmy grupy docelowe. Bardzo jasno wiemy, że to są takie, a takie kobiety. Znamy ich problemy, bo rozmawialiśmy z nimi. (Projektantka 3)

Kolejna rozmówczyni poproszona o przybliżenie swoich refleksji dotyczących obrazu kobiety pracującej w branży IT zaznaczyła kilka cech wyglądu i osobowości:

Myślę, że jest bardzo bystra i inteligentna, że ma bardzo duże wymagania, zwraca uwagę na detale, ma bardzo analityczny umysł, aczkolwiek bardzo często połączony z takim kreatywnym myśleniem. Jest to osoba, która dąży do realizacji różnych wyzwań, nie boi się rozwiązywać problemów. Trochę bym ją określiła jako „wojowniczkę”. (Projektantka 7)

Powyższa wypowiedź przedstawia interpretacje projektantki o intelekcie kobiet, przyporządkowując jego wysoki poziom do stanowiska w branży technologicznej. Pojawiają się tutaj także elementy stereotypowe łączące analityczne myślenie z samą branżą. Istotny pod względem podkreślania własnych przekonań jest sposób mówienia o personach, tutaj modelowa użytkowniczka została nazwana „wojowniczką”. Pojawiło się też kilka wypowiedzi zaznaczających obraz i rozumienie męskości w perspektywie badanych projektantów. Jeden z moich rozmówców opisywał swoje wyobrażenia o użytkowniku strony przeznaczonej dla mężczyzn w Arabii Saudyjskiej.

Bardzo ciężko było sobie wyobrazić typowego użytkownika, ponieważ, to były osoby z Arabii, czy z Dubaju. [...] Tam bardziej operowałem (jeśli chodzi o wygląd) troszkę na stereotypach, ale bardziej chodziło o to, aby zaprezentować, że to jest jednak realny człowiek, no ale jeśli chodzi o pozostałe rzeczy, to kierowałem się danymi. W przypadku, gdy nie jestem w stanie sobie bezpośrednio wyobrazić takiej osoby, to bardziej opieram się na danych, które są dostępne ogólnie. (Projektant 4)

W wypowiedzi badany podkreślił, że jest świadomy swoich stereotypowych założeń. Jednocześnie zaznaczył, że wiedzę o użytkownikach opiera na danych pochodzących z etapu badawczego. W tym przypadku strona dotyczyła motoryzacji i najwięcej wniosków, które zostały uznane za istotne względem celu biznesowego produktu, pochodziło z rozmów z mężczyznami.

Badani często odnosili się do danych zebranych w trakcie analizy przeprowadzanych wywiadów i ankiet. Projektantka zajmująca się przygotowaniem aplikacji w branży finansowej opisała powody, dla których zdecydowano się na męskie persony.

Miałam na samym początku projekt taki, że robiliśmy aplikację inwestycyjną i tu było tak, że miałam dwie persony i obie były męskie. Wynikało to stąd, że sam produkt, sama ta usługa raczej wpasowuje się w taki „męski klimat”, bo gdzieś na samym początku czuliśmy, że jest to gdzieś powiedzmy „,bardziej dla facetów”, bo to chodziło o takie „mocne inwestowanie”. Czuliśmy, że jest to bardziej produkt, którym będą mocniej zainteresowani mężczyźni niż kobiety. (Projektantka 2) 
Poprosiłam moją rozmówczynię o doprecyzowanie „męskiego klimatu”, a dokładniej tego, w jaki sposób został on zinterpretowany w projekcie aplikacji. W swojej odpowiedzi projektantka zaznaczyła, że miała na myśli elementy graficzne, a dokładniej kolory i kształty „typowe” dla mężczyzn. Zdaniem badanej oznacza to stosowanie na stronie prostokątów, kwadratów oraz skupienie się na treściach zawierających fonty bezszeryfowe. W odniesieniu do teorii istnieje wiele różnych cech typowo męskich lub kobiecych, które łączone w pary określeń, często skonstruowane są na zasadzie opozycji. W badaniach Inge Brovermana i jego współpracowników za „rdzeń” stereotypów związanych z płcią uznano po dwie pary stereotypowych cech - kompetencję i racjonalność jako cechy męskie oraz ciepło i ekspresyjność jako cechy typowo kobiece (Broverman 1972: 59-78). Jedna z badanych, mówiąc o procesach graficznych, podkreśla urzeczywistnienie takich etykiet $\mathrm{w}$ formie na przykład kolorystyki:

Wydaje mi się, że w takich procesach już dalszych, bardziej graficznych, to na pewno mam wrażenie, że dużym wyznacznikiem jest kolor, czyli zazwyczaj te właśnie takie męskie aplikacje, na przykład gry bukmacherskie, to są ciemne kolory, na ciemnym tle, takie rzeczy mi się tak na pierwszy rzut oka kojarzą. (Projektantka 2)

Powyższe skojarzenia z męskością i kobiecością pokazują, że są one binarnie konstruowane przez badanych projektantów. Pojawia się tutaj kilka dychotomii na poziomie wdrażanych do projektów elementów wizualnych lub kojarzenie użytkowniczek z emocjonalnością, a użytkowników z myśleniem analitycznym. Jak pisze Dębska, interpretując koncepcję kobiecości i męskości w ujęciu Pierre’a Bourdieu: „Męskość i kobiecość współwytwarza się zrozumiale wyłącznie w relacji, we wzajemnym przeciwstawieniu, gdzie mężczyzna ma być wszystkim tym, czym nie jest kobieta" (Dębska 2015: 23). Podział ten został zaznaczony przez moich rozmówców przez wyróżnienie elementów projektowanych rozwiązań, które definiują płeć odbiorców.

Odkrywając doświadczenia badanych związane z pracą nad rozwiązaniami skierowanymi do danej płci, poprosiłam o podzielenie się ich wyobrażeniami o finalnych efektach ich projektów. Mam na myśli stosowane zabiegi lub elementy interfejsów nadające zdaniem rozmówców cechy kobiecości lub męskości. Projektanci i projektantki w swoich odpowiedziach zgodnie podkreślali, że podstawowym wyróżnikiem rozgraniczającym płeć odbiorców na stronach jest kolor. Badani przypisali paletę ciemnych barw do produktów dla mężczyzn oraz pastelowych, jasnych i różowych dla kobiet.

W przypadku kobiet używa się oprócz różu kolorów delikatniejszych i pastelowych. Natomiast u mężczyzn oprócz tych niebieskości i granatów bardzo często jest to kolor ciemnoczerwony, który też wzmaga w percepcji agresję, a agresja wzrost testosteronu, który z kolei może wpływać na decyzję zakupowe. Wydaje mi się, że psychologia koloru jest ważnym zagadnieniem, który jest wart pogłębienia. (Projektantka 5)

W kilku wypowiedziach rozmówcy pytani o wyjaśnienie użycia konkretnego odcienia na przykład do tła strony odnosili się do psychologii kolorów lub przyjętych reguł w środowisku projektantów. Moi badani w ten sposób naturalizują płeć i wpisują w porządek rzeczy. Porządek ten, jak pisał Bourdieu, podkreśla różnice między płciami, która jest wpisana w „porządek rzeczy - jak się czasem mówi, chcąc określić to, co »normalne«, »naturalne«, a więc w jakiś 
Płeć społeczno-kulturowa jako kategoria różnicująca proces projektowy...

sposób nieuniknione” (Dębska 2015). Wymienione „rzeczy” w odniesieniu do wypowiedzi moich rozmówców przyjmują formę kolorów i kształtów.

Jest pewna paleta kolorów uznawana za damskie, paleta kolorów uznawana za męskie i ogólnie przyjmuje się w świecie projektanckim, że ciemniejsze kolory są raczej skierowane do mężczyzn, jaśniejsze i ciepłe są skierowane do kobiet. (Projektantka 3)

W tym miejscu znajduję analogię do podziału analizowanego przez Bourdieu bazującego na ,systemie homologicznych opozycji: wysoki/niski, nad/pod, przed/za, prawy/lewy, prosty/ krzywy (ale też pokrętny)" (Bourdieu 2004:16). Dwie z wymienionych dychotomii mają odzwierciedlenie w wypowiedziach dotyczących warstwy wizualnej. Mam na myśli tutaj podział na jasny/ciemny czy prosty/krzywy w przypadku kształtu przycisków na projektowanych stronach. W rozmowach $\mathrm{z}$ badanymi na temat kolorystyki pojawiały się nawiązania do kwestii stereotypów. W bardziej lub mniej świadomy sposób projektanci określali swoje podejście jako „stereotypowe”. Poniżej kilka wybranych odpowiedzi potwierdzających moje obserwacje:

Oprócz tego różowego - tutaj jestem chyba w jakimś stereotypie, bo ten różowy mi się stricte z kobietami kojarzy. (Projektantka 1)

Tak - różowy... stereotypowo, ale użyliśmy blady różowy, beżowy. Generalnie bardzo ciepłe kolory. (Projektantka 3)

Gdzie wydaje mi się, że strona dla kobiety musi być bardziej taka delikatna, jak font, to nie taki techniczny, tylko jakieś zaokrąglone kształty, kolorystyka popadająca w jakieś pastele i róże, niż np. zielony czy niebieski, więcej obrazków, zdjęć. Z tym mi się tak stereotypowo, taka strona kojarzy. (Projektantka 7)

Jeśli mamy tak podchodzić totalnie stereotypowo do tego, no to nie wiem... Może dla kobiet będą jakieś pastelowe kolory. [...] I znowu, jeśli mamy na to patrzeć stereotypowo, to jakieś ciemne, męskie kolory. (Projektantka 8)

Podczas rozmów o końcowej kolorystyce projektowanych stron i aplikacji pojawiały się elementy oraz zabiegi mające na celu zwrócenie uwagi odbiorców określonej płci. Jedna $\mathrm{z}$ badanych opisywała realizację projektu skierowanego do młodych rodziców.

[...] Gdzie wiadomo, że opieką nad dziećmi statystycznie częściej zajmują się kobiety. Tamten projekt był stricte zaprojektowany pod kobiety, bo wszędzie były uśmiechnięte i radosne twarze dzieci. A wiadomo, że kobiety podchodzą do tego typu serwisów, w ogóle wszystkiego bardziej emocjonalnie i zwracają większą uwagę na twarze, które są dostępne w interfejsach. A już zwłaszcza jeśli chodzi o słodkie małe bobasy. (Projektantka 5)

Moja rozmówczyni zaznacza w swoich wypowiedziach, że cechą charakterystyczną użytkowniczek jest emocjonalne podejście do relacji i świata. Podczas projektowania stron znajduje ono swoje odzwierciedlenie w zdjęciach dzieci lub umiejscowieniu przycisku zakupowego na wysokości wzroku postaci z grafiki. Warto zwrócić uwagę na słowa projektantki, która podkreśla, że opiekowaniem się dziećmi zajmują się częściej kobiety. Dodając do swojej 
wypowiedzi sformułowanie, że jest to „wiadome”, zaznacza swoje przekonania. Kolejne odpowiedzi również nadawały wysokie znaczenie zdjęciom, które podkreślały adresowanie produktu do kobiet.

[...] zdecydowanie, wizerunki kobiet, również, jeśli chodzi o zdjęcia użyte na stronie. (Projektantka 1)

To wszystko wpisuje się w stylistykę produktu, ale też widać od samego początku jak się wejdzie na tą stronę, to pierwsze zdjęcie, to są właśnie dwie kobiety. (Projektantka 2)

Kolorystyka, zdecydowanie, wizerunki kobiet, również, jeśli chodzi o zdjęcia użyte na stronie. (Projektantka 3)

Pozostałe elementy, jakie badani przyporządkowali do stron i aplikacji charakterystycznych dla użytkowniczek, to wyboldowane teksty lub zabiegi w postaci odpowiednio umieszczonych przycisków zakupu.

Bardzo często jeżeli nie mamy zdefiniowanego pod względem płci użytkownika, ale chcemy, żeby kobiety częściej klikały, to stosuje się właśnie umieszczanie „Call to action button” w pobliżu jakiejś twarzy, która to twarz ma skierowany wzrok na ten przycisk. (Projektantka 5)

Jedna z badanych zwróciła uwagę na stosowanie odpowiedniego pisma dla stron i aplikacji poświęconym kobietom. Ten sam pogląd podziela również Projektantka 6, która odręczne pismo uważa za cechę portali kobiecych. Zwróciła również uwagę na stosowanie męskich końcówek na stronach skierowanych dla odbiorców ogółem, a żeńskich tylko w tych dla użytkowniczek. Obraz płci, jaki wyłania się z tych wypowiedzi, wyraźnie zaznacza definiowanie kobiecości poprzez delikatność czy emocjonalne podejście, które projektanci próbują uchwycić, stosując takie zabiegi jak odręczne pismo na stronie czy stosowanie feminatywów.

To, w jaki sposób jest rozumiana męskość w projektach UX rozmówców, stoi w opozycji do przedstawienia elementów widocznych na stronach i aplikacjach definiujących kobiecość. Sandra Bem uważa, że przekonanie o polaryzacji płciowej jest jednym z kluczowych schematów poznawczych w kulturze zachodniej. Autorka odnosi się do koncepcji androcentryzmu, który „polega na stawianiu pierwiastka męskiego i wartości męskich w centrum uwagi. Męskie doświadczenie jest w tym podejściu traktowane jako uniwersalne dla wszystkich ludzi, standardowe i neutralne, natomiast kobiece doświadczenie jest odchyleniem od normy, typowym wyłącznie dla kobiet" (Kamasz 2016: 1). Często badani zaznaczali, że do rozgraniczenia męskości i kobiecości w projektach stosują odmienny typ treści zawartych na stronie. W przypadku męskich odbiorców są to techniczne treści, statystyki oraz „konkrety” i „twarde dane". Natomiast w produktach skierowanych do kobiet stosuje się nawiązanie do wartości i „miękkich aspektów”.

Drugą personą, w trochę innej części, w aspekcie klienta, [...] była kobieta. Kobiety na stanowisku dyrektorskim odpowiadały za merytorykę, więc tam się podzieliło: dyrektorzy odpowiedzialni za zarządzanie biznesem to byli mężczyźni, a dyrektorki odpowiadały za merytorykę, do nich kierowaliśmy ten sam produkt, ale był inny komunikat. Tam uderzyliśmy bardziej w wartości, było przeniesienie bardziej ,jak możesz zastosować”, jak przenieść np. relacje do pracy z dziećmi, czyli raczej miękkie aspekty, a w tamtym były twarde. (Projektantka 3 ) 
Płeć społeczno-kulturowa jako kategoria różnicująca proces projektowy...

Trzecia rozmówczyni opisywała realizację projektu strony dla przedszkoli i szkół prywatnych. Zdaniem badanej większość osób na stanowiskach kierowniczych w danej placówce to mężczyźni, dlatego pierwszorzędna persona była męska. W tym przypadku poprosiłam projektantkę o przedstawienie szczegółów dotyczących strony wizualnej i treści.

Tutaj mocniej celowaliśmy w to, że jedną z cech persony było to, że był to mężczyzna, ale drugą ważną cechą jest to, że była to osoba mocno analityczna, więc kolory w to uderzały. Był to niebieski, który mocno kojarzy się z analizą, czy granatowy. Natomiast bardziej chodzi o komunikaty. To były konkretne statystyki, liczby, bardzo krótkie rzeczy, ale to nie tyle dotyczyło mężczyzn, co po prostu persony, bo ona miała analityczny umysł, to było skierowane do dyrektorów i miało usprawniać ich zarządzanie biznesem, więc musiały być tam konkrety. (Projektantka 3)

Odnosząc się do literatury, zdaniem Ann Oakley, klasyfikacja tego, co jest społecznie i kulturowo uznane za „męskie” oraz za „kobiece” charakteryzuje się społeczną nierównością (Królikowska 2011: 389). Nierówność tę można zaobserwować w wypowiedzi jednego z projektantów, który widzi ją w treściach na stronie, której odbiorcami są mężczyźni. Badany, podobnie jak Projektantka 3, twierdzi, że treści o charakterze technicznym sprawdzają się w realizacji projektów skierowanych do mężczyzn:

Jeśli chodzi o elementy samej aplikacji, które były bardziej skierowane do mężczyzn, to tak jak już wspominałem, to będą te treści stricte techniczne, np. moc silnika, kilka takich rubryczek bardzo mocno technicznych odnośnie samochodu. (Projektant 4)

Chcąc pogłębić temat stereotypowego myślenia, poprosiłam moich rozmówców o przedstawienie źródeł inspiracji projektowych. Celem było znalezienie powtarzających się schematów dotyczących kolorystyki. W trakcie rozmów pojawiały się te same strony skierowane między innymi do projektantów i projektantek UX - Behance i Dribble.

Jeżeli chodzi o same inspiracje, przeglądam Dribbla, niby to jest bardzo designowe, ale pod kątem UXowym, to też jest spoko, bo można zobaczyć, jakie są różne rozwiązania, na Behance jest dużo case study. (Projektantka 1)

W trakcie rozmów odniosłam wrażenie, że badani są świadomi pojawiających się stereotypów. Często podkreślali to wypowiedziami „Wiem, że to stereotypowe podejście, ale..." Zwłaszcza w odpowiedzi na pytania dotyczące wyobrażeń o doświadczenia końcowych użytkowników. Jednoczesne podkreślenie istniejących w projektach przekonań było neutralizowane poprzez duży nacisk na pozyskiwanie danych o użytkownikach $\mathrm{z}$ badań user experience.

\section{PODSUMOWANIE}

Obraz płci społeczno-kulturowej, jaki wyłania się z przeprowadzonych rozmów, podkreśla jej dychotomiczność na wielu płaszczyznach. Pierwszym etapem różnicującym treści procesu projektowego jest przygotowanie person (modelowych użytkowników produktu). Dane, które 
są potrzebne do ich tworzenia, często są zaczerpnięte z własnych przekonań projektantów. Mimo że każdy z respondentów podkreślał duże znaczenie i konieczność przeprowadzania badań, zanim powstanie persona, to pojawiały się wypowiedzi o tym, że czasami tworzone są one na podstawie własnych przekonań czy intuicji projektantów ${ }^{11}$.

Kolejnym etapem projektowania doświadczeń użytkowników zawierającym elementy płci jest proces łączenia danych zebranych z badań i person ze stroną wizualną tworzonych produktów cyfrowych. Treści, które różnicują ten etap procesu pod względem płci odbiorców, to kolorystyka, kształty, zdjęcia, treści oraz odmienne rodzaje fontów. Jeżeli chodzi o zastosowanie barw, to dla produktów skierowanych dla kobiet badani używali pastelowej lub bardzo jasnej palety kolorów - w przeciwieństwie do męskiej kategorii projektów, gdzie dominowały na przykład ciemne odcienie granatu. Kolejny punkt to kształty przycisków projektowanych stron i aplikacji. Zdecydowana większość badanych przypisuje obłe kształty użytkowniczkom, a kanciaste elementy stają się charakterystyczne dla męskich odbiorców produktów. W rozmowach pojawił się także temat odmiennych treści zróżnicowanych ze względu na płeć. Strony i aplikacje dla kobiet miały teksty nawiązujące do bardziej emocjonalnego podejścia użytkowniczek. Natomiast dla męskich odbiorców były prezentowane treści techniczne, zawierające statystyki zaznaczające analityczne podejście do ich interpretacji.

Projektanci, którzy wzięli udział w przeprowadzonych wywiadach, zaznaczali często, że są świadomi występowania stereotypów w trakcie pracy nad projektami tworzonymi z myślą o danej płci odbiorców. Etap przeprowadzania badań i analizy wynikających z niego danych był rozumiany jako działanie chroniące przed ich nadmiernym pojawianiem się w trakcie faz tworzenia produktu. Myślę, że warto tutaj zaznaczyć, że w tak nowoczesnym zawodzie jak projektant user experience wciąż są obecne tradycyjne przekonania o płci, a dychotomia płci nie zmienia się mimo rosnącej egalitaryzacji społeczeństw.

\section{BIBLIOGRAFIA}

Adam, Alison. 2006. Artificial knowing: Gender and the thinking machine, London: Routledge. Asberg, Cecilia i Nina Lykke. 2010. Feminist technoscience studies, „European Journal of Women's Studies", 17, 4: 299-305.

Bath, Corinna i Jutta Weber. 2007. Social” robots \& "emotional” software agents: Gendering processes and de-gendering strategies for "technologies in the making, w: Isabel Zorn, Susanne Maass, Els Rommes, Carola Schirmer I Heidi Schelhowe (ed.), Gender Designs IT. Construction and Deconstruction of Information Society Technology, Wiesbaden: VS Verlag für Sozialwissenschaften, s. 53-63.

Barbee Teasley, Laura Leventhal, Brad Blumenthal, Keith Instone i Daryl Stone. 1994. Cultural diversity in user interface design: are intuitions enough?, „SIGCHI Bull”, 26, 1: 36-40.

11 Nicola Marsden w artykule Doing UX: Doing Gender wspomina o znaczeniu intuicji w projektowaniu „Projektanci UX padają ofiarą własnych stereotypów, ufając intuicji co do tego jakie kolory lub kształty mogą podobać się odbiorcom: kobietom i mężczyznom, tworzą upłciowione interfejsy” (Marsden 2014). 
Płeć społeczno-kulturowa jako kategoria różnicująca proces projektowy...

Bardzell, Shaowen. 2010. Feminist HCI: taking stock and outlining an agenda for design, w: CHI '10: Proceedings of the SIGCHI Conference on Human Factors in Computing Systems, New York: Association for Computing Machinery, s. 1301-1310.

Beckwith Laura, Margaret Burnett, Susan Wiedenbeck, Curtis Cook, Shraddha Sorte i Michelle Hastings. 2005. Effectiveness of end-user debugging software features: Are there gender issues?, w: CHI '05: Proceedings of the SIGCHI Conference on Human Factors in Computing Systems, New York: Association for Computing Machinery, s. 869-878.

Bradley, Harriet. 2008. Płeć, tłum. Ewa Chomicka, Warszawa: Wydawnictwo Sic!

Butler, Judith. 1990. Gender Trouble: Feminism and the Subversion of Identity, London: Routledge.

Broverman, Inge. 1972. Sex-Role Stereotypes: A Current Appraisal, „Social Issues”, 28, 2: $59-78$

Cao, Cuicui, Ling Zhao i Yingying Hu. 2019. Anthropomorphism of Intelligent Personal Assistants (IPAs): Antecedents and Consequences, w: PACIS 2019 Proceedings, 187, https:// aisel.aisnet.org/pacis2019/187 [20.08.2020].

Carroll, John. Human Computer Interaction - brief intro, w: The Encyclopedia of HumanComputer Interaction, https:/www.interaction-design.org/literature/book/the-encyclopedia-of-human-computer-interaction-2nd-ed/human-computer-interaction-brief-intro [18.08.2020].

Carpenter, Julie, Joan M. Davis, Norah Erwin-Stewart, Tiffany R. Lee, John D. Bransford i Nancy Vye. 2009. Gender representation and humanoid robots designed for domestic use, „International Journal of Social Robotics”, 1: 261-265.

Cassell, Justine. 2002. Genderizing human-computer interaction, w: The human-computer interaction handbook: fundamentals, evolving technologies and emerging applications, 2nd ed., New York: L. Erlbaum Associates Inc., s. 401-412, http:/www.economics.rpi. edu/public_html/ruiz/EGDSpring2013/readings/gender.hci.just.pdf [09.08.2020].

Castells, Manuel. 2008. Siła tożsamości, Warszawa: Wydawnictwo Naukowe PWN.

Cockburn, Cynthia i Susan Ormrod. 1993. Gender and Technology in the Making, SAGE Publications Ltd.

Connell, Raewyn. 2013. Socjologia płci. Płeć w ujęciu globalnym, tłum. Olga Siara, Warszawa: Wydawnictwo Naukowe PWN.

Dębska, Hanna. 2015. Somatyzacja dominacji. Ciało w teorii socjologicznej Pierre'a Bourdieu, „Studia Sociologica”, VII, 1: 18-38.

Eyssel, Friederike i Frank Hegel. 2012. (S)he's Got the Look: Gender Stereotyping of Robots 1, „Journal of Applied Social Psychology”, 42, 9: 1-18.

Faulkner, Wendy. 1998. Extraordinary journeys around ordinary technologies in ordinary lives, „Social Studies of Science”, 28, 3: 484-489.

Faulkner, Wendy. 2001. The technology question in feminism: A view from feminist technology studies, „Women's Studies International Forum”, 24, 1: 79-95.

Fonseca, Sabrina. 2017. Designing forms for gender diversity and inclusion, https:/uxdesign.cc/designing-forms-for-gender-diversity-and-inclusion-d8194cf1f51 [10.08.2020].

Goban-Klas, Tomasz. 1999. Media i komunikowanie masowe. Teorie i analizy prasy, radia, telewizji i Internetu, Warszawa - Kraków: Wydawnictwo Naukowe PWN. 
Haraway, Donna. 1998. Manifest cyborga, przeł. Ewa Franus, http://www.magazynsztuki. home.pl/post_modern/9.html [20.08.2020].

Hofmann, Jeanette. 1999. Writers, texts and writing acts, w: Judy Wajcman i Donald MacKenzie. The Social Shaping of Technology, Buckingham, UK - Philadelphia: Open University Press, s. 222- 243.

Kamasz, Ewelina. 2016. Wptyw konstrukcji androcentrycznych na postrzeganie mężczyzn $i$ kobiet w życiu codziennym i polityce, w: Hanna Liberska (red.), Zmiany w życiu wspótczesnych ludzi i ich konteksty, Warszawa: Diffin.

Królikowska, Sabina. 2011. Rola stereotypów ptci w kształtowaniu postaw kobiet i mężczyzn wobec zdrowia, „Nowiny Lekarskie”, 80, 5: 387-393.

Kvale, Steinar. 2004. InterViews, wprowadzenie do jakościowego wywiadu badawczego, Białystok: TransHumana.

Lee, Eun Ju, Clifford Nass i Scott Brave. 2000. Can computer-generated speech have gender? An experimental test of gender stereotype, w: CHI EA '00: $C H I$ '00 Extended Abstracts on Human Factors in Computing Systems, New York: Association for Computing Machinery, s. 289-290.

Leszczyńska, Katarzyna i Agata Dziuban. 2012. Pomiędzy esencjalizmem a konstruktywizmem. Pteć (kulturowa) w refleksji teoretycznej socjologii - przeglad koncepcji, „Studia Humanistyczne AGH”, 11, 2: 13-34.

Lohan, María. 2000. Constructive Tensions in Feminist Technology Studies, „Social Studies of Science", 30, 6: 895-916.

Lowdermilk, Travis. 2013. User-Centered Design, Sebastapol: O’Reilly Media.

Marcus, Aaron. 1993. Human communication issues in advanced UIs', „Communications of the ACM", 36, 4: 100-109.

Marshall, Daniel. 2002. Ideological Discourses in the Making of Internet Career Sites, „Journal of Computer-Mediated Communication", 7, 4: 142-144.

Marsden, Nicola. 2014. Doing UX: Doing Gender, „User Experience Magazine”, 14, 1, https://uxpamagazine.org/doing-ux/ [20.08.2019].

Mościchowska, Iga, Barbara Rogoś i Ewa Sobula. 2011. Raport: Kariera w UX, https://pobieranie.dlastudenta.pl/studia/pdf/Raport_Kariera_w_UX_UXbite_2011.pdf [12.07.2019].

Nomura, Tatsuya. 2017. Robots and gender, „Gender and the Genome”, 1, 1: 18-25.

Pujol, Joan i Marisela Montenegro. 2015. Technology and feminism: A strange couple, „Revista de Estudios Sociales", 51: 173-185.

Querini, Vale. 2020. How to design for every gender?, https://careerfoundry.com/en/blog/ ux-design/design-for-every-gender/ [14.08.2020].

Rodger, James A. i Parag C. Pendharkar. 2004. A field study of the impact of gender and user's technical experience on the performance of voice-activated medical tracking application, „International Journal of Human Computer Studies”, 60, 5-6: 529-544.

Siegel, Mikey, Cynthia Breazeal i Michael I. Norton. 2009. Persuasive robotics: The influence of robot gender on human behavior, w: 2009 IEEE/RSJ International Conference on Intelligent Robots and Systems, s. 2563-2568. 
Stawicki, Henryk. O projektowaniu zorientowanym na człowieka, https://www.swps.pl/strefadesignu/blog/19926-o-projektowaniu-zorientowanym-na-czlowieka [16.08.2020].

Tidwell, Jenifer. 2012. Sprawdzone wzorce projektowe. Projektowanie interfejsów, Gliwice: Helion, O’Reilly.

\section{GENDER AS A DIFFERENTIATING CATEGORY OF THE USER EXPERIENCE DESIGN PROCESS}

This article approached the concept of gender category in the new technology industry, especially in the user experience (UX) design process. The research problem relates to the question of how gender differentiates the user experience design process? According to the analysis of the qualitative method (Individual In-depth Interview) the author distinguished elements that diversify the UX design process from a gender perspective. The main issues contained in colors, content, shapes, photos, graphics displayed on websites and apps dedicated to gender-specific users. The research included designers and researchers who are responsible for building user experience in web and mobile application projects.

Keywords: user experience, feminist HCI, user-centered design, gender, human-computer interaction

Zgłoszenie artykułu: 10.09.2019

Recenzje: 8.12.2019

Rewizja: 2.10 .2020

Akceptacja: 4.10.2020

Publikacja on-line: 30.03 .2021

(C) 2021 Autorka. Jest to publikacja ogólnodostępna, którą można wykorzystywać, rozpowszechniać i kopiować w dowolnej formie zgodnie z licencją Creative Commons CC-BY 4.0 